CLINICAL STUDY

\title{
Low plasma triiodothyronine levels in heart failure are associated with a reduced anabolic state and membrane damage
}

\author{
Gabriela Brenta, Jorge Thierer ${ }^{1}$, Marcela Sutton ${ }^{1}$, Adriana Acosta ${ }^{1}$, Nora Vainstein ${ }^{1}$, Fernando Brites ${ }^{2}$, \\ Laura Boero ${ }^{2}$, Leonardo Gómez Rosso ${ }^{2}$ and Stefan Anker ${ }^{3,4}$ \\ Department of Endocrinology, Cesar Milstein Hospital, La Rioja, CABA 1221, Buenos Aires, Argentina, ${ }^{1}$ Cardiovascular Institute of Buenos Aires (ICBA), \\ Buenos Aires, Argentina, ${ }^{2}$ School of Pharmacy and Biochemistry, University of Buenos Aires, Buenos Aires, Argentina, ${ }^{3}$ Applied Cachexia Research, \\ Department of Cardiology, Charité Universitätsmedizin Berlin, Campus Virchow-Klinkum, Berlin, Germany and ${ }^{4}$ Centre for Clinical and Basic Research, \\ IRCCS San Raffaele, Rome, Italy \\ (Correspondence should be addressed to G Brenta; Email: gbrenta@gmail.com)
}

\begin{abstract}
Background: Low plasma triiodothyronine $\left(\mathrm{T}_{3}\right)$ levels are considered a prognostic predictor of death in heart failure (HF) patients.

Aim: To study an association between plasma $\mathrm{T}_{3}$ levels and several cardiac, neurohormonal, and metabolic markers of HF.

Methods: A total of 133 ambulatory HF patients (114 males; mean age 63.2 years) with left ventricular ejection fraction $<40 \%$ were enrolled. TSH, total tetraiodothyronine $\left(\mathrm{T}_{4}\right)$ and $\mathrm{T}_{3}, \mathrm{~N}$-terminal pro-brain natriuretic peptide (NT-proBNP), and other cardiac and metabolic parameters were measured. The lowest tertile of $\mathrm{T}_{3}$ (group 1) was compared against the two upper ones (group 2).

Results: In simple logistic regression, the lowest $\mathrm{T}_{3}$ tertile was associated with more advanced $\mathrm{HF}$ disease status: older (age: odds ratio $(\mathrm{OR})=1.05$; confidence interval $(\mathrm{CI}) 95 \% 1.01-1.09, P=0.004$ ), lower functional capacity (walking test: $\mathrm{OR}=0.996$; CI 95\% 0.993-0.999, $P=0.008$ ), higher NT-proBNP $(\mathrm{OR}=1.64$; CI 95\% 1.19-2.27, $P=0.003)$ and adiponectin levels $(\mathrm{OR}=1.07$; CI $95 \%$ $1.02-1.11, P=0.004)$, lower DHEAS log-transformed ( $\mathrm{OR}=0.50$; CI 95\% 0.31-0.80, $P=0.004)$, and the presence of lower phase angle values as measured by body bioelectrical impedance analysis $(\mathrm{OR}=3.18$; CI 95\% 1.50-6.71, $\mathrm{P}=0.04)$ and worse renal function $(\mathrm{OR}=0.96$; CI 95\% 0.94-0.98, $P=0.003) . T_{3}$ levels in the lowest tertile were independently associated with low phase angle values $(\mathrm{OR}=2.95$, CI 95\% 1.16-7.50, $\mathrm{P}=0.02)$ and the log transformation of DHEAS $(\mathrm{OR}=0.56$; CI 95\% $0.32-0.97, P=0.04)$.

Conclusion: We have demonstrated an association between plasma $\mathrm{T}_{3}$ levels in the lower range and other deranged hormonal and metabolic parameters in HF patients.
\end{abstract}

European Journal of Endocrinology 164 937-942

\section{Introduction}

Euthyroid sick syndrome and non-thyroidal illness syndrome are the terms currently used to define a condition characterized by an impairment of the hypothalamus-pituitary-thyroid axis present in most critically ill patients. A fall in serum triiodothyronine $\left(\mathrm{T}_{3}\right)$, also known as low $\mathrm{T}_{3}$ syndrome, is one of the most common changes observed (1-3). This pathological process has been found to be present in about 30\% of congestive heart failure (HF) patients. Those patients classified as New York Heart Association (NYHA) functional class III-IV (4) have shown a higher prevalence of low $\mathrm{T}_{3}$ levels. Furthermore, the low $\mathrm{T}_{3}$ syndrome in $\mathrm{HF}$ is considered a predictor of death $(5,6)$.
Several changes consistent with the downregulation of the thyroid hormone signaling system take place in the advanced failing heart and postinfarcted myocardium. This hypothyroid phenotype includes a lower expression of thyroid hormone receptor- $\alpha 1$ (TR $\alpha 1$ or THRA), sarcoplasmic reticulum calcium ATPase (SERCA2 or ATP2A2), and higher expression of $\beta$ myosin genes (7-9). Although these changes in cardiac phenotype might be due to low circulating levels of thyroid hormones in HF, impaired thyroid hormone signaling might also result from the re-expression of deiodinase type 3 (D3), the local thyroid hormone inactivating enzyme, in cardiomyocytes $(10,11)$.

Reversal of this hypothyroid phenotype with physiological replacement of $\mathrm{T}_{3}$ might prove beneficial as been shown in animal models of HF where left ventricular 
contractile performance was improved (12) or with ventricular ischemia where early long-term $\mathrm{L}_{-} \mathrm{T}_{3}$ replacement has been shown to preserve the mitochondria and prevent ischemic cardiac remodeling (13). Moreover, studies of short-term $\mathrm{T}_{3}$ replacement in patients undergoing coronary artery bypass surgery and in patients with advanced HF have also demonstrated a hemodynamic benefit with such therapy (14-16).

It can be argued that low $\mathrm{T}_{3}$ levels present in $\mathrm{HF}$ might not just indicate disease progression but they might have a pathophysiological role. This might be explained by the direct effects of low $\mathrm{T}_{3}$ levels in the cardiovascular system and/or through a possible interaction with catabolic and inflammatory parameters also present in HF (17). This is in line with the idea that the pathophysiological phenomenon behind HF initially involves a compensatory activation of hormonal, immunological, and proinflammatory systems. However, a later phase ensues where all of these compensatory responses eventually become maladaptive (18). The use of markers such as brain natriuretic peptide (BNP) (19) or adiponectin (20), which provide prognostic information of adverse outcome in HF, is well established. However, an interaction between $\mathrm{T}_{3}$ levels and catabolic parameters present in HF still remains a matter of interest for further research.

In this study, we explored a possible association of low $\mathrm{T}_{3}$ circulating levels with some of the hemodynamic, neurohormonal, and metabolic prognostic parameters present in congestive HF patients.

\section{Materials and methods}

\section{Subjects}

We prospectively included 151 consecutive ambulatory patients with systolic HF referred to our institute between May 2005 and March 2007 in the MIMICA study, designed to explain the relationship between metabolic and inflammatory markers and severity of disease (21). All patients had left ventricular ejection fraction (LVEF) $\leq 40 \%$ and were in a stable condition (not hospitalized because of decompensated HF, nor required a visit to emergency department or a raise of the diuretic dose) at least for 3 months prior to their inclusion in the study. After excluding overt hypothyroid and hyperthyroid patients, 133 patients remained to be included in the present analysis. Overt hypothyroidism was defined as TSH values $>5.0 \mu \mathrm{IU} / \mathrm{ml}$ and total tetraiodothyronine $\left(\mathrm{T}_{4}\right)$ values $<4.5 \mu \mathrm{g} / \mathrm{dl}$. Overt hyperthyroidism was defined as TSH values $<0.3 \mu \mathrm{IU} / \mathrm{ml}$ and $\mathrm{T}_{4}$ values $>13 \mu \mathrm{g} / \mathrm{dl}$.

\section{Blood sampling and analysis}

Following a $12 \mathrm{~h}$ overnight fast, venous blood was obtained from the antecubital vein. Hematological parameters, urea, creatinine, glycemia, baseline insulin, liver, and cholesterol panels were determined. We measured high-sensitivity C-reactive protein (hsCRP), uric acid, leptin, adiponectin, albumin, cortisol and DHEAS, and N-terminal pro-BNP (NT-proBNP).

For determination of hsCRP, leptin, adiponectin, NT-proBNP, cortisol, and DHEAS, all the samples were processed in the same assay.

hsCRP was determined by Tina-quant CRP (Latex, Mannheim, Germany) high-sensitive immunoturbidimetric assay (Roche Diagnostics) in a Hitachi 917 autoanalyzer. The intra assay coefficient of variation (CV) was $0.43 \%$.

Leptin was measured by IRMA (Active Human Leptin IRMA, Diagnostic System Laboratories, Inc., Webster, TX, USA). The intra assay $\mathrm{CV}$ of the assay at $3.0 \mathrm{ng} / \mathrm{ml}$ was $3.9 \%$ and at $12 \mathrm{ng} / \mathrm{ml}$ was $1.7 \%$.

Adiponectin was determined by enzyme immunoassay (Quantikine Human Adiponectin/Acrp30 Immunoassay. R\&D Systems, Inc., Minneapolis, MN, USA). The intra assay CV of the assay at $19.8 \mu \mathrm{g} / \mathrm{ml}$ was $2.5 \%$.

NT-proBNP was determined by immunoassay (proBNP Elecsys Roche Diagnostics $\mathrm{GmbH}$ ). The intra assay $\mathrm{CV}$ was $2.7 \%$.

Plasmatic and urinary cortisol levels were evaluated by immunoassay (Access Cortisol, Beckman Coulter, Fullerton, CA, USA). The intra assay CV was $6.4 \%$ for plasmatic and $4 \%$ for urinary-free cortisol.

DHEAS was assessed by RIA (Coat-A-Count DHEAS$\mathrm{SO}_{4}$ Diagnostic Products Corporation, Los Angelas, CA, USA). The intra assay $\mathrm{CV}$ was below $5.3 \%$.

$\mathrm{TSH}, \mathrm{T}_{3}$, and $\mathrm{T}_{4}$ were determined by electrochemiluminescence immunoassay (Elecsys 1010-ROCHE Diagnostic). TSH reference values were $0.3-5.0 \mu \mathrm{IU} / \mathrm{ml}$. Intra assay $\mathrm{CV} \%$ was $2 \%$ and inter assay $\mathrm{CV}$ was $3.7 \%$ using a human serum sample with $0.9 \mu \mathrm{IU} / \mathrm{ml}$ (EP5Modified protocol of National Committee of Clinical Laboratories Standards, NCCLS). Analytical sensitivity of the method was: 0.005 and functional sensitivity was $0.014 \mu \mathrm{IU} / \mathrm{ml}$.

$\mathrm{T}_{4}$ reference values were $4.5-13.0 \mu \mathrm{g} / \mathrm{dl}$. Intra assay CV\% was $2.9 \%$ and inter assay $\mathrm{CV}$ was $3.9 \%$ using a human serum sample with $9.0 \mu \mathrm{g} / \mathrm{dl}$ in six daily assays during 10 days (EP5-A, NCCLS).

$\mathrm{T}_{3}$ reference values were $0.8-2.0 \mathrm{ng} / \mathrm{ml}$. Intra assay CV\% was $4.1 \%$ and inter assay CV was $4.9 \%$ using a human serum sample with $2.1 \mathrm{ng} / \mathrm{ml}$ in six daily assays during 10 days (EP5-A, NCCLS). Analytical sensitivity was $0.195 \mathrm{ng} / \mathrm{ml}$.

In non-diabetic patients, insulin resistance was calculated by the homeostasis model assessment index for insulin resistance $($ HOMA-IR $)=($ fasting plasma glucose $(\mathrm{mg} / \mathrm{dl}) \times$ fasting plasma insulin $(\mu \mathrm{IU} / \mathrm{ml})) /$ $(18 \times 22.5)$.

\section{Echocardiography}

The acquisition of echocardiographic data was performed using the Philips iE33 Ultrasound. 
M-mode left ventricular dimensions were obtained from the parasternal long-axis view following the standard Echocardiography American guidelines, determining left ventricle diastolic and systolic diameters, interventricular septum, posterior wall, and aortic root. Left atrial area was traced in apical four-chamber view.

Ventricular function was performed in four-chamber apical view: the endocardial border was manually traced in end systole and end diastole and using the Simpson method (biplane), left ventricular end diastolic volume, left ventricular end systolic volume, and ejection fraction were assessed.

\section{Six minutes walking test}

Functional capacity was assessed with the 6 min walking test, performed in a flat straight $30 \mathrm{~m}$ corridor. The test was conducted under the control of an experienced physician who encouraged the patients to walk in the corridor at a higher rate from one extremity to the other as much time as possible. Patients were allowed to stop if necessary but were urged to resume the walk as soon as they recovered. Baseline and final heart rate and systolic blood pressure were recorded. The distance walked in $6 \mathrm{~min}(6 \mathrm{MWD})$ is expressed in meters.

\section{Bioelectrical impedance analysis}

In every patient, body composition (muscle mass, fat mass content, and total, intra- and extracellular water) was assessed by body bioelectrical impedance analysis (BIA). All the tests were performed by the same skilled physician using a tetrapolar and multiple frequency equipment (four-channel bioimpedance meter BioScan MSR-916, Maltron International Ltd, Rayleigh, UK). BIA has been validated as a suitable method to determine body composition and is well correlated with dual-energy X-ray absorptiometry (22). The method is based on the resistance encountered through water and the body tissues during low-intensity electric current passage. The two electrodes are placed on the palm and wrist as well as the other two electrodes on the foot sole and ankle; all electrodes are placed on the right side of the body. In order to perform the test, the patient has to remain lying down on the supine position, in a fasted condition for the last $6 \mathrm{~h}$ and having avoided strenuous exercise within the last $12 \mathrm{~h}$. Determination of phase angle, a marker of membrane damage, was also assessed (22). Low phase angle, a marker of membrane damage, was defined as $<5.5$ degrees in women or $<6.5$ degrees in men.

\section{Protocol}

All tests were carried out within 5 days of inclusion, at the Instituto Cardiovascular de Buenos Aires. The investigation complied with the principles outlined in the Declaration of Helsinki. The protocol was approved by the institutional ethics committee and signed informed consent was obtained from each participant.

In order to explore the relationship between low $\mathrm{T}_{3}$ values and the baseline parameters, the population was divided into tertiles of $\mathrm{T}_{3}$, and the lowest tertile (group 1 ) was compared against the two upper ones (group 2).

\section{Statistical analysis}

Categorical variables are presented as percentages and continuous variables as mean \pm s.D. when their distribution was normal, or median and interquartile range when it was not.

Comparisons between the two groups were performed by Student's $t$-test (continuous variables) or $\chi^{2}$ test (categorical variables). Simple and multiple logistic regressions were performed to define variables significantly associated with the lowest tertile of $\mathrm{T}_{3}$. Logarithmic transformation was performed to achieve a normal distribution for skewed variables and to introduce them in the multivariable analysis.

Statistical analysis was performed with Stata 10 package (StataCorp, College Station, TX, USA).

\section{Results}

\section{Baseline characteristics}

Of the 133 patients, $114(85.7 \%)$ were males and mean age was $63.2 \pm 11.5$ years; $9.7 \%$ were cigarette smokers, $24.8 \%$ diabetic, $54.9 \%$ had arterial

Table 1 Comparison of demographic parameters, clinical characteristics, heart failure disease status, and use of drugs between group 1 and group 2 patients.

\begin{tabular}{llll}
\hline & $\begin{array}{l}\text { Group 1 } \\
n=45\end{array}$ & $\begin{array}{l}\text { Group 2 } \\
n=88\end{array}$ & P value \\
\hline Male sex (\%) & 88.8 & 81.8 & 0.29 \\
Age (years) & $67.2 \pm 11.6$ & $60.9 \pm 11.8$ & 0.002 \\
Diabetes (\%) & 28.9 & 23.8 & 0.53 \\
Hypertension (\%) & 46.6 & 55.6 & 0.32 \\
Ischemic etiology (\%) & 62.2 & 48.8 & 0.14 \\
NYHA Ill-IV (\%) & 35.5 & 22.7 & 0.11 \\
Atrial fibrillation (\%) & $15.5 \%$ & $6.8 \%$ & 0.11 \\
$\beta$-Blockers (\%) & $95.5 \%$ & $89.8 \%$ & 0.25 \\
ACEl-ARB (\%) & $73.3 \%$ & $85.2 \%$ & 0.10 \\
Amiodarone (\%) & $46.6 \%$ & $31.8 \%$ & 0.09 \\
Diuretics (\%) & $93.3 \%$ & $75 \%$ & 0.01 \\
Digitalis (\%) & $28.8 \%$ & $19.3 \%$ & 0.21 \\
LVEF & $28.2 \pm 7.8$ & $28.4 \pm 7.7$ & 0.90 \\
6 min walking test (mts) & $251 \pm 132$ & $320 \pm 136$ & 0.006 \\
Resting metabolic rate (kcal) & $1416 \pm 208$ & $1487 \pm 244$ & 0.09 \\
Fat-free mass (\%) & $70.6 \pm 7.4 \%$ & $68.9 \pm 7.9$ & 0.22 \\
Phase angle (degrees) & $6.5 \pm 2.2$ & $7.2 \pm 2.1$ & 0.08 \\
Low phase angle (\%) & 62.2 & 34.1 & 0.002 \\
\hline
\end{tabular}

BMI, body mass index; NYHA III-IV, New York Heart Association functional class III-IV; ACEI, angiotensin-converting enzyme inhibitor; ARB, angiotensin receptor blocker; LVEF, left ventricular ejection fraction. 
Table 2 Comparison of biochemical values between group 1 and group 2 patients.

\begin{tabular}{llll}
\hline & $\begin{array}{l}\text { Group 1 } \\
n=45\end{array}$ & $\begin{array}{l}\text { Group 2 } \\
n=88\end{array}$ & $\begin{array}{c}\boldsymbol{P} \\
\text { value }\end{array}$ \\
\hline Hemoglobin (g/dl) & $13.8 \pm 1.5$ & $14.1 \pm 1.5$ & 0.26 \\
GFR (ml/min/1.73 m²) & $52 \pm 18$ & $62 \pm 17$ & 0.002 \\
WBC count & $7.2 \pm 1.9$ & $7.3 \pm 1.4$ & 0.74 \\
$\quad\left(1000 / \mathrm{mm}^{3}\right)$ & & & \\
$\mathrm{Na}(\mathrm{meq} / \mathrm{l})$ & $140 \pm 4$ & $141 \pm 3$ & 0.16 \\
$\mathrm{~K}(\mathrm{meq} / \mathrm{l})$ & $4.7 \pm 0.4$ & $4.7 \pm 0.4$ & 0.63 \\
HOMA-IR & $2.3 \pm 1.5$ & $3.1 \pm 2.5$ & 0.09 \\
Cholesterol (mg/dl) & $188 \pm 41$ & $199 \pm 60$ & 0.32 \\
Leptin $(\mathrm{ng} / \mathrm{ml})$ & $9.5 \pm 6.8$ & $9.7 \pm 6.1$ & 0.86 \\
Cortisol $(\mu \mathrm{g} / \mathrm{dl})$ & $16.9 \pm 4.9$ & $16.1 \pm 4.8$ & 0.30 \\
DHEAS $(\mu \mathrm{g} / \mathrm{dl})$ & $40(24-70)$ & $63(40-99)$ & 0.003 \\
$\mathrm{hsCRP}(\mathrm{mg} / \mathrm{l})$ & $2.7(1.3-5.4)$ & $2.7(1.3-5.7)$ & 0.96 \\
NT-proBNP $(\mathrm{pg} / \mathrm{ml})$ & $1350(956-2676)$ & $794(235-1703)$ & 0.0004 \\
Adiponectin $(\mu \mathrm{g} / \mathrm{ml})$ & $16.8 \pm 7.4$ & $12.3 \pm 7.9$ & 0.002 \\
$\mathrm{~T}_{3}(\mathrm{ng} / \mathrm{ml})$ & $0.83 \pm 0.07$ & $1.14 \pm 0.16$ & 0.0001 \\
$\mathrm{~T}_{4}(\mu \mathrm{g} / \mathrm{dl})$ & $8.6 \pm 1.8$ & $7.9 \pm 1.3$ & 0.028 \\
TSH $(\mu \mathrm{ll} / \mathrm{ml})$ & $2.6 \pm 2.3$ & $3.3 \pm 2.5$ & 0.12 \\
\hline
\end{tabular}

GFR, glomerular filtration rate; WBC, white blood cell; HOMA-IR, homeostasis model assessment index for insulin resistance; hsCRP, high-sensitivity C-reactive protein; NT-proBNP, N-terminal pro-brain natriuretic peptide; $\mathrm{T}_{3}$, triiodothyronine; $\mathrm{T}_{4}$, total tetraiodothyronine.

hypertension, 50.4\% had ischemic etiology, $42.8 \%$ had previous myocardial infarction, and $27.1 \%$ were classified as functional class NYHA III-IV. Mean LVEF was $28.3 \pm 7.9 \%$ and mean 6 min walking distance was $293 \pm 140 \mathrm{mts}$. The vast majority of the patients used $\beta$-blockers (90.2\%) and angiotensin-converting enzyme inhibitor (ACEI) and an angiotensin receptor blocker (ARB), ACEI-ARB (80.4\%). Approximately one-third of our patients $(36.8 \%)$ were on amiodarone.

$\mathrm{T}_{3}$ values ranged from 0.57 to $1.68 \mathrm{ng} / \mathrm{ml}$. Mean $\mathrm{T}_{3}$ value was $1.03 \pm 0.20 \mathrm{ng} / \mathrm{ml}$.

\section{Comparison of groups}

The cutoff point between groups 1 and 2 was $0.95 \mathrm{ng} / \mathrm{ml}$.

Tables 1 and 2 show the comparison of measured parameters between groups. Group 1 patients (low $\mathrm{T}_{3}$ values) were significantly older, with higher use of diuretics, and a trend to be more symptomatic and more frequently treated with amiodarone. They presented with less than 6 min walking distance, worse renal function, lower levels of DHEAS, and higher NT-proBNP and adiponectin values. Their phase angle was lower, and the prevalence of low phase angle was higher. LVEF, left ventricular diameters and volumes, and E/A relation were not significantly different among tertiles.

In simple logistic regression (Table 3 ), the lowest $\mathrm{T}_{3}$ tertile was associated with more advanced HF disease status: older, lower functional capacity, higher NT-proBNP and adiponectin levels, lower DHEAS logtransformed, and the presence of low phase angle values and worse renal function.

In multiple logistic regression (Table 3), the lowest tertile of $\mathrm{T}_{3}$ was independently associated with low phase angle values (odds ratio $(\mathrm{OR})=2.95$, confidence interval (CI) 95\% 1.16-7.50, $P=0.02$ ) and the $\log$ transformation of DHEAS $(\mathrm{OR}=0.58$; CI 95\% $0.37-0.92, P=0.022$ ).

\section{Discussion}

In this study, we have shown for the first time that low $\mathrm{T}_{3}$ levels, a strong indicator of poor prognosis in $\mathrm{HF}$, are associated with lower BIA phase angle (a marker of membrane damage) and lower DHEAS (expression of diminished anabolic status). The association was independent of the influence of other recognized markers of HF such as age, weight loss, renal function, or muscle mass.

NT-proBNP also appeared related to lower $\mathrm{T}_{3}$ levels, with significantly higher levels in group 1 patients. NT-proBNP levels are used for screening, diagnosis of acute $\mathrm{HF}$, and to establish prognosis in HF. Higher levels imply a worse outcome (23). It has previously been shown that free $\mathrm{T}_{3}$ is significantly related to NT-proBNP in patients with cardiovascular disease. Moreover, both parameters exert an independent and additively prognostic value for mortality in $\operatorname{HF}(24,25)$. In agreement with these studies, as previously mentioned, we also

Table 3 Variables significantly associated with the lower $T_{3}$ tertile in univariate and multiple logistic regressions.

\begin{tabular}{|c|c|c|c|c|c|c|}
\hline \multirow[b]{2}{*}{ Variables } & \multicolumn{3}{|c|}{ Simple logistic regression } & \multicolumn{3}{|c|}{ Multiple logistic regression } \\
\hline & OR & $\mathrm{Cl} 95 \%$ & $P$ & OR & $\mathrm{Cl} 95 \%$ & $P$ \\
\hline Age (years) & 1.05 & $1.01-1.09$ & 0.004 & 0.98 & $0.93-1.03$ & 0.51 \\
\hline Functional class III-IV & 1.87 & $0.85-4.12$ & 0.11 & 1.29 & $0.50-3.28$ & 0.59 \\
\hline Amiodarone use & 1.87 & $0.89-3.92$ & 0.09 & 1.65 & $0.68-3.98$ & 0.26 \\
\hline 6 min walking test (mts) & 0.996 & $0.993-0.999$ & 0.008 & 0.999 & $0.995-1.003$ & 0.72 \\
\hline GFR $\left(\mathrm{ml} / \mathrm{min} / 1.73 \mathrm{~m}^{2}\right)$ & 0.96 & $0.94-0.98$ & 0.003 & 0.97 & $0.95-1.00$ & 0.15 \\
\hline DHEAS log value & 0.50 & $0.31-0.80$ & 0.004 & 0.56 & $0.32-0.97$ & 0.04 \\
\hline NT-proBNP log value & 1.64 & $1.19-2.27$ & 0.003 & 1.09 & $0.72-1.64$ & 0.68 \\
\hline Adiponectin $(\mu \mathrm{g} / \mathrm{ml})$ & 1.07 & $1.02-1.11$ & 0.004 & 1.03 & $0.97-1.09$ & 0.26 \\
\hline Low phase angle & 3.18 & $1.51-6.72$ & 0.002 & 2.95 & $1.16-7.50$ & 0.02 \\
\hline
\end{tabular}

$\mathrm{Cl}$, confidence interval; OR, odds ratio; GFR, glomerular filtration rate; NT-proBNP, N-terminal pro-brain natriuretic peptide. 
found higher levels of NT-proBNP in patients with lower levels of $\mathrm{T}_{3}$.

A novel association between low $\mathrm{T}_{3}$ levels in $\mathrm{HF}$ and the adrenal steroid DHEAS was revealed in this study. It has previously been reported that plasma levels of DHEA are decreased in patients with HF (26) and that they can be used as a prognostic marker of bad outcome in HF (27). Although alternative explanations for the lower levels of this anabolic hormone in HF have been offered $(28,29)$, lower DHEAS levels in HF could also be interpreted in the light of a hypothyroid state. Lower DHEAS levels have previously been reported in hypothyroid women (30). It has been suggested that the lower concentrations of DHEA and DHEAS in hypothyroidism could be explained by decreased adrenal steroidogenesis (31). Moreover, an indirect regulation by thyroid hormones of human DHEA sulfotransferase family $1 \mathrm{~A}$ member 2 (SULT2A1), the enzyme that catalyzes sulfonation of DHEA to DHEAS has been reported and could also be playing a role in lower DHEAS levels described in hypothyroidism (32). On the other hand, given that oxidative stress is present in hypothyroid patients (33), lower DHEAS levels found in our low $\mathrm{T}_{3}$ patients could also be explained through a decrease in 17,20-lyase activity.

We evaluated body composition using whole-body BIA method and found that the chances of pertaining to the low $\mathrm{T}_{3}$ group increased nearly three times when phase angle was low. A lower phase angle implies cell death or decreased cell integrity (34). With regard to HF, it has been described that bioimpedance phase angles are lower in patients with functional class NYHA III-IV compared with those with NYHA I-II (35). In agreement with our findings, a smaller phase angle after 6 months of follow-up was observed in HF patients who developed some alteration in the thyroid profile when compared with the rest of the cohort (36).

A limitation of our study is the high use of amiodarone found in the low $\mathrm{T}_{3}$ group. Due to its big iodine load, amiodarone can decrease conversion of $\mathrm{T}_{4}$ to $\mathrm{T}_{3}$ yielding low serum $\mathrm{T}_{3}$ levels. However, to discard its possible effects as a confounder, amiodarone use, together with other parameters such as age, that has been also reportedly associated with lower $\mathrm{T}_{3}$ values, was adjusted within the multivariable analysis and was not independently related to low $\mathrm{T}_{3}$ levels. Furthermore, our group of patients with the lowest $\mathrm{T}_{3}$ levels was in a more advanced HF status and this is in line with authors that reported that concomitant amiodarone therapy does not have a relevant influence in the higher mortality rate found in HF patients with low $\mathrm{T}_{3}$ (37).

On the other hand, the strengths of this study lie on the multiplicity of metabolic and neurohormonal parameters included. The reported findings are original and should be considered hypothesis generating.

In conclusion, we have found that low $\mathrm{T}_{3}$ levels in $\mathrm{HF}$ patients are associated with several markers of illness. Lower anabolic activity and more severe membrane damage could partially explain a more advanced HF status among patients with low $\mathrm{T}_{3}$ levels.

\section{Declaration of interest}

The authors declare that there is no conflict of interest that could be perceived as prejudicing the impartiality of the research reported.

\section{Funding}

This research did not receive any specific grant from any funding agency in the public, commercial, or not-for-profit sector.

\section{References}

1 Wartofsky L \& Burman KD. Alterations in thyroid function in patients with systemic illness: the "euthyroid sick syndrome". Endocrine Reviews 19823 164-217. (doi:10.1210/edrv-3-2-164)

2 DeGroot LJ. "Non-thyroidal illness syndrome" is functional central hypothyroidism, and if severe, hormone replacement is appropriate in light of present knowledge. Journal of Endocrinological Investigation 200326 1163-1170.

3 Peeters RP, Debaveye Y, Fliers E \& Visser TJ. Changes within the thyroid axis during critical illness. Critical Care Clinics 200622 41-55. (doi:10.1016/j.ccc.2005.08.006)

4 Ascheim DD \& Hryniewicz K. Thyroid hormone metabolism in patients with congestive heart failure: the low triiodothyronine state. Thyroid 200212 511-515. (doi:10.1089/105072502760 143908)

5 Iervasi G, Pingitore A, Landi P, Raciti M, Ripoli A, Scarlattini M, L'Abbate A \& Donato L. Low-T 3 syndrome: a strong prognostic predictor of death in patients with heart disease. Circulation 2003 107 708-713. (doi:10.1161/01.CIR.0000048124.64204.3F)

6 Pingitore A, Landi P, Taddei MC, Ripoli A, L'Abbate A \& Iervasi G. Triiodothyronine levels for risk stratification of patients with chronic heart failure. American Journal of Medicine $2005 \mathbf{1 1 8}$ 132-136. (doi:10.1016/j.amjmed.2004.07.052)

7 Rouf R, Greytak S, Wooten EC, Wu J, Boltax J, Picard M, Svensson EC, Dillmann WH, Patten RD \& Huggins GS. Increased FOG-2 in failing myocardium disrupts thyroid hormone-dependent SERCA2 gene transcription. Circulation Research $2008 \mathbf{1 0 3}$ 493-501. (doi:10.1161/CIRCRESAHA.108.181487)

8 Kinugawa K, Yonekura K, Ribeiro RC, Eto Y, Aoyagi T, Baxter JD, Camacho SA, Bristow MR, Long CS \& Simpson PC. Regulation of thyroid hormone receptor isoforms in physiological and pathological cardiac hypertrophy. Circulation Research 200189 591-598. (doi:10.1161/hh1901.096706)

9 Ojamaa K, Kenessey A, Shenoy R \& Klein I. Thyroid hormone metabolism and cardiac gene expression after acute myocardial infarction in the rat. American Journal of Physiology. Endocrinology and Metabolism 2000279 E1319-E1324.

10 Simonides WS, Mulcahey MA, Redout EM, Muller A, Zuidwijk MJ, Visser TJ, Wassen FW, Crescenzi A, da-Silva WS, Harney J, Engel FB, Obregon MJ, Larsen PR, Bianco AC \& Huang SA. Hypoxia-inducible factor induces local thyroid hormone inactivation during hypoxic-ischemic disease in rats. Journal of Clinical Investigation 2008118 975-983. (doi:10.1172/JCI32824)

11 Olivares EL, Marassi MP, Fortunato RS, da Silva AC, Costae-Sousa RH, Araujo IG, Mattos EC, Masuda MO, Mulcahey MA, Huang SA, Bianco AC \& Carvalho DP. Thyroid function disturbance and type 3 iodothyronine deiodinase induction after myocardial infarction in rats a time course study. Endocrinology 2007148 4786-4792. (doi:10.1210/en.2007-0043)

12 Henderson KK, Danzi S, Paul JT, Leya G, Klein I \& Samarel AM. Physiological replacement of $\mathrm{T}_{3}$ improves left ventricular function 
in an animal model of myocardial infarction-induced congestive heart failure. Circulation. Heart Failure 20092 243-252. (doi:10. 1161/CIRCHEARTFAILURE.108.810747)

13 Forini F, Lionetti V, Ardehali H, Pucci A, Cecchetti F, Ghanefar M, Nicolini G, Ichikawa Y, Nannipieri M, Recchia FA \& Iervasi G. Early long-term $\mathrm{L}-\mathrm{T}_{3}$ replacement rescues mitochondria and prevents ischemic cardiac remodeling in rats. Journal of Cellular and Molecular Medicine 201015 514-524. (doi:10.1111/j.15824934.2010.01014.x)

14 Klein I \& Danzi S. Thyroid hormone treatment to mend a broken heart. Journal of Clinical Endocrinology and Metabolism 200893 1172-1174. (doi:10.1210/jc.2008-0291)

15 Hamilton MA, Stevenson LW, Fonarow GC, Steimle A, Goldhaber JI, Child JS, Chopra IJ, Moriguchi JD \& Hage A. Safety and hemodynamic effects of intravenous triiodothyronine in advanced congestive heart failure. American Journal of Cardiology 199881 443-447. (doi:10.1016/S0002-9149(97)00950-8)

16 Pingitore A, Galli E, Barison A, Iervasi A, Scarlattini M, Nucci D, L'Abbate A, Mariotti R \& Iervasi G. Acute effects of triiodothyronine replacement therapy in patients with chronic heart failure and low- $\mathrm{T}_{3}$ syndrome: a randomized, placebo-controlled study. Journal of Clinical Endocrinology and Metabolism 200893 1351-1358. (doi:10.1210/jc.2007-2210)

17 Lubrano V, Pingitore A, Carpi A \& Iervasi G. Relationship between triiodothyronine and proinflammatory cytokines in chronic heart failure. Biomedicine and Pharmacotherapy 201064 165-169. (doi:10.1016/j.biopha.2009.09.001)

18 Packer M. The neurohormonal hypothesis: a theory to explain the mechanism of disease progression in heart failure. Journal of the American College of Cardiology 199220 248-254. (doi:10.1016/ 0735-1097(92)90167-L)

19 Tsutamoto T, Wada A, Maeda K, Hisanaga T, Maeda Y, Fukai D, Ohnishi M, Sugimoto Y \& Kinoshita M. Attenuation of compensation of endogenous cardiac natriuretic peptide system in chronic heart failure: prognostic role of plasma brain natriuretic peptide concentration in patients with chronic symptomatic left ventricular dysfunction. Circulation 199796 509-516.

20 Kistorp C, Faber J, Galatius S, Gustafsson F, Frystyk J, Flyvbjerg A \& Hildebrandt P. Plasma adiponectin, body mass index, and mortality in patients with chronic heart failure. Circulation 2005112 1756-1762. (doi:10.1161/CIRCULATIONAHA.104.530972)

21 Thierer J, Acosta A, Vainstein N, Sultan M, Francesia A, Marino J, Prado AH, Guglielmone R, Trivi M, Boero L, Brites F \& Anker S. Relation of left ventricular ejection fraction and functional capacity with metabolism and inflammation in chronic heart failure with reduced ejection fraction (from the MIMICA Study). American Journal of Cardiology 2010105 977-983. (doi:10.1016/ j.amjcard.2009.11.017)

22 Baumgartner RN, Chumlea WC \& Roche AF. Bioelectric impedance phase angle and body composition. American Journal of Clinical Nutrition $1988 \mathbf{4 8} 16-23$.

23 Bhalla V, Willis S \& Maisel AS. B-type natriuretic peptide: the level and the drug - partners in the diagnosis of congestive heart failure. Congestive Heart Failure 200410 3-27. (doi:10.1111/ j.1527-5299.2004.03310.x)

24 Passino C, Pingitore A, Landi P, Fontana M, Zyw L, Clerico A, Emdin M \& Iervasi G. Prognostic value of combined measurement of brain natriuretic peptide and triiodothyronine in heart failure. Journal of Cardiac Failure 200915 35-40. (doi:10.1016/j.cardfail. 2008.08.008)

25 Pfister R, Strack N, Wielckens K, Malchau G, Erdmann E \& Schneider CA. The relationship and prognostic impact of low- $\mathrm{T}_{3}$ syndrome and NT-pro-BNP in cardiovascular patients. International Journal of Cardiology $2009 \quad \mathbf{1 4 4} \quad 187-190$ (doi: 10.1016/j.ijcard.2009.03.137). (doi:10.1016/j.ijcard.2009. 03.137)
26 Anker SD, Chua TP, Ponikowski P, Harrington D, Swan JW, Kox WJ, Poole-Wilson PA \& Coats AJ. Hormonal changes and catabolic/anabolic imbalance in chronic heart failure and their importance for cardiac cachexia. Circulation 199796 526-534.

27 Jankowska EA, Biel B, Majda J, Szklarska A, Lopuszanska M, Medras M, Anker SD, Banasiak W, Poole-Wilson PA \& Ponikowski P. Anabolic deficiency in men with chronic heart failure: prevalence and detrimental impact on survival. Circulation 2006114 1829-1837. (doi:10.1161/CIRCULATIONAHA.106. 649426)

28 Moriyama Y, Yasue H, Yoshimura M, Mizuno Y, Nishiyama K, Tsunoda R, Kawano H, Kugiyama K, Ogawa H, Saito Y \& Nakao K. The plasma levels of dehydroepiandrosterone sulfate are decreased in patients with chronic heart failure. Journal of Clinical Endocrinology and Metabolism 200085 1834-1840. (doi:10. $1210 /$ jc. 85.5 .1834 )

29 Nawata H, Ohashi M, Haji M, Takayanagi R, Higuchi K, Fujio N, Hashiguchi T, Ogo A, Nakao R, Ohnaka K \& Nishi Y. Atrial and brain natriuretic peptide in adrenal steroidogenesis. Journal of Steroid Biochemistry and Molecular Biology 199140 367-379. (doi:10.1016/0960-0760(91)90204-I)

30 Bassi F, Pupi A, Giannotti P, Fiorelli G, Forti G, Pinchera A \& Serio M. Plasma dehydroepiandrosterone sulphate in hypothyroid premenopausal women. Clinical Endocrinology 198013 111-113. (doi:10.1111/j.1365-2265.1980.tb01031.x)

31 Tagawa N, Tamanaka J, Fujinami A, Kobayashi Y, Takano T, Fukata S, Kuma K, Tada H \& Amino N. Serum dehydroepiandrosterone, dehydroepiandrosterone sulfate, and pregnenolone sulfate concentrations in patients with hyperthyroidism and hypothyroidism. Clinical Chemistry 200046 523-528.

32 Huang YH, Lee CY, Tai PJ, Yen CC, Liao CY, Chen WJ, Liao CJ, Cheng WL, Chen RN, Wu SM, Wang CS \& Lin KH. Indirect regulation of human dehydroepiandrosterone sulfotransferase family 1 A member 2 by thyroid hormones. Endocrinology 2006 147 2481-2489. (doi:10.1210/en.2005-1166)

33 Torun AN, Kulaksizoglu S, Kulaksizoglu M, Pamuk BO, Isbilen E \& Tutuncu NB. Serum total antioxidant status and lipid peroxidation marker malondialdehyde levels in overt and subclinical hypothyroidism. Clinical Endocrinology 200970 469-474. (doi:10.1111/ j.1365-2265.2008.03348.x)

34 Selberg O \& Selberg D. Norms and correlates of bioimpedance phase angle in healthy human subjects, hospitalized patients, and patients with liver cirrhosis. European Journal of Applied Physiology 200286 509-516. (doi:10.1007/s00421-0010570-4)

35 Castillo Martínez L, Colín Ramírez E, Orea Tejeda A, Asensio Lafuente E, Bernal Rosales LP, Rebollar González V, Narváez David R \& Dorantes García J. Bioelectrical impedance and strength measurements in patients with heart failure: comparison with functional class. Nutrition 200723 412-418. (doi:10.1016/j.nut. 2007.02.005)

36 Silva-Tinoco R, Castillo-Martínez L, Orea-Tejeda A, OrozcoGutiérrez JJ, Vázquez-Díaz O, Montaño-Hernández P, FloresRebollar A \& Reza-Albarrán A. Developing thyroid disorders is associated with poor prognosis factors in patient with stable chronic heart failure. International Journal of Cardiology 2009147 e24-e25. (doi:10.1016/j.ijcard.2009.01.012)

37 Coceani M, Molinaro S, Scalese M, Landi P, Carpeggiani C, L'abbate A, Iervasi G \& Pingitore A. Thyroid hormone, amiodarone therapy, and prognosis in left ventricular systolic dysfunction. Journal of Endocrinological Investigation 2011 In press. (doi:10.3275/ 7351)

Received 15 March 2011

Accepted 31 March 2011 